\title{
PENGARUH OPM, ROE DAN ROA TERHADAP PERUBAHAN LABA PADA PERUSAHAAN LEMBAGA PEMBIAYAAN DI INDONESIA
}

\author{
Surya Perdana ${ }^{1}$, Eni Hartanti ${ }^{2}$ \\ Program Studi Teknik Industri Fakultas Teknik, Matematika dan IPA, \\ Universitas Indraprasta PGRI \\ Email: suryaperdana.st.mm@gmail.com
}

\begin{abstract}
The purpose of this study was to examine the effect of operating profit margin, return on equity and return on assets to changes in earnings in multifinance companies in Indonesia Stock Exchange. This study is used a secondary data from financial statements on 12 multifinance companies in Indonesia Stock Exchange from 2011 untill 2015. This study uses panel data regression of a combined cross section data and time series.

The result of this study showed that operating profit margin, return on equity and return on assets simultaneously have a significant influence to changes in earnings. The result of $F$-test showed that the significant level is $0,00<0,05$. The result of $t$-test, operating profit margin (OPM) has negative and no significant influence to changes in earnings. Return on equity (ROE) has positive and significant influence to changes in earnings. Return on asset (ROA) has positive and significant influence to changes in earnings.
\end{abstract}

Keywords: Operating Profit Margin, , Return on Equity, Return on Asset, Changes Earnings

\begin{abstract}
ABSTRAK
Penelitian ini bertujuan untuk mengetahui pengaruh operating profit margin, return on equity dan return on assets terhadap perubahan laba pada perusahaan lembaga pembiayaan yang terdaftar di Bursa Efek Indonesia. Penelitian ini menggunakan data sekunder berupa data laporan keuangan 12 sampel perusahaan pembiayaan yang diperoleh dari Bursa Efek Indonesia periode 2011-2015. Penelitian ini menggunakan regresi data panel yaitu gabungan data cross section dan time series. Hasil penelitian menunjukkan bahwa operating profit margin (OPM), return on asset (ROA), dan return on equity (ROE) secara simultan memiliki pengaruh yang signifikan terhadap perubahan laba. Hasil uji $\mathrm{F}$ menghasilkan tingkat signifikansi $0,00<0,05$. Hasil uji-t, operating profit margin (OPM) berpengaruh negatif dan tidak signifikan terhadap perubahan laba. Return on equity (ROE) berpengaruh positif dan signifikan terhadap perubahan laba. Return on asset (ROA) berpengaruh positif dan signifikan terhadap perubahan laba.
\end{abstract}

Kata Kunci: Operating Profit Margin, , Return on Equity, Return on Asset, Perubahan laba 


\section{PENDAHULUAN}

Di dunia investasi saat ini, investor harus lebih cermat dalam memilih perusahaan untuk menanamkan sejumlah dana dalam rangka meraih keuntungan atas investasi tersebut. Oleh karena itu analisis terhadap kinerja perusahaan sangatlah penting. Suatu perusahaan yang dianggap prospektif untuk berinvestasi dapat diartikan sebagai perusahaan yang memberikan profit atau laba di masa yang akan datang. Laba yang merupakan elemen paling menjadi perhatian karena angka laba diharapkan cukup kaya dalam merepresentasikan kinerja perusahaan secara keseluruhan. Dengan tingkat laba yang memadai, menjamin pendapatan untuk para kreditor dan pemegang saham. Semakin besar tingkat laba maka akan menambah kepercayaan pihak deposan dan investor.

Dengan menggunakan analisis rasio keuangan kita dapat membantu memprediksi perubahan laba di masa depan. Jenis rasio keuangan sangat banyak jumlahnya, para pemakai laporan keuangan dapat menentukan jenis rasio yang akan dipakai sesuai dengan kebutuhan mereka. Rasio keuangan yang digunakan dalam penelitian ini antara lain operating profit margin (OPM), return on equity (ROE) dan return on assets (ROA). Rasio keuangan OPM, ROE dan ROA merupakan rasio profitabilitas. Menurut Kasmir (2014) tujuan rasio profitabilias secara umum adalah untuk mengukur atau menghitung laba yang dihasilkan, menilai perkembangan laba dari waktu ke waktu, menilai besarnya laba bersih sesudah pajak dengan modal sendiri, mengukur produktivitas perusahaan dari seluruh dana perusahaan yang digunakan baik modal pinjaman maupun modal sendiri dan tujuan lainnya.

Dipilihnya perusahaan lembaga pembiayaan sebagai objek penelitian ini karena merupakan salah satu perusahaan yang memegang peranan penting dalam kebutuhan masyarakat akan jasa kredit baik untuk usaha maupun kebutuhan konsumtif. Dengan tingginya minat kebutuhan konsumen, semakin besar pula persaingan dalam dunia usaha ini yang dapat mengakibatkan perubahan laba pada periode-periode berikutnya.

Rerangka Pemikiran dan Pengembangan Hipotesis

\section{Pengaruh OPM, ROE dan ROA terhadap Perubahan Laba}

Operating Profit Margin, Return On Equity dan Return On Assets merupakan rasio profitabilitas. Salah satu tujuan rasio profitabilitas menurut Kasmir (2014) adalah menilai perkembangan laba dari waktu ke waktu. Berdasarkan teori tersebut, hipotesis dapat dinyatakan sebagai berikut:

H1 : Operating Profit Margin, Return On Equity dan Return On Assets secara simultan berpengaruh terhadap perubahan laba

\section{Pengaruh OPM terhadap Perubahan Laba}

Operating profit margin menggambarkan kemampuan perusahaan menghasilkan laba pada tingkat penjualan tertentu. Rasio ini mengukur kemampuan untuk menghasilkan laba sebelum bunga dan pajak dengan penjualan yang dicapai perusahaan. Rasio ini menunjukkan efisiensi bagian produksi, personalia serta pemasaran dalam menghasilkan laba (Sudana, 2011). Operating profit margin menunjukkan kemampuan perusahaan untuk menghasilkan laba berdasarkan penjualan sehingga memiliki nilai prediktif dalam menghasilkan laba (Widhi, 2011). Hal ini didukung oleh penelitian sebelumnya yang dilakukan oleh Syamni dan Martunis (2013) dengan hasil penelitian yang menyimpulkan bahwa OPM berpengaruh positif dan signifikan terhadap perubahan laba. Berdasarkan teori tersebut, hipotesis dapat dinyatakan sebagai berikut :

H2 : Operating Profit Margin secara parsial berpengaruh terhadap perubahan laba.

\section{Pengaruh ROE terhadap Perubahan Laba}

Menurut Suwarno dalam Wibowo dan Pujiati (2011) Pengaruh rasio return on equity terhadap perubahan laba bersih perusahaan adalah semakin tinggi nilai rasio ini maka semakin tinggi pula tingkat laba yang dihasilkan karena penambahan modal kerja dapat digunakan untuk membiayai operasi perusahaan yang akhirnya dapat menghasilkan laba. Hal ini didukung oleh penelitian sebelumnya yang dilakukan oleh Syarifah (2014) dengan hasil penelitian yang menyimpulkan bahwa ROE berpengaruh positif dan signifikan terhadap perubahan laba. Berdasarkan teori tersebut, hipotesis dapat dinyatakan sebagai berikut :

H3 : Return On Equity secara parsial berpengaruh terhadap perubahan laba.

\section{Pengaruh ROA terhadap Perubahan Laba} Menurut Hanafi dan Halim (2007) Rasio ini mengukur kemampuan perusahaan menghasilkan 
laba bersih berdasarkan tingkat aset yang tertentu. ROA berfungsi untuk mengukur efektivitas perusahaan dalam menghasilkan laba dengan memanfaatkan aktiva yang dimiliki. Semakin besar ROA yang dimiliki oleh sebuah perusahaan maka semakin efesien penggunaan aktiva sehingga akan memperbesar laba. Hal ini didukung oleh penelitian sebelumnya yang dilakukan oleh Syamni dan Martunis (2013) serta Naser (2011) yang menyimpulkan bahwa ROA berpengaruh positif dan signifikan terhadap perubahan laba. Berdasarkan teori tersebut, hipotesis dapat dinyatakan sebagai berikut:

H4 : Return On Assets secara parsial berpengaruh terhadap perubahan laba

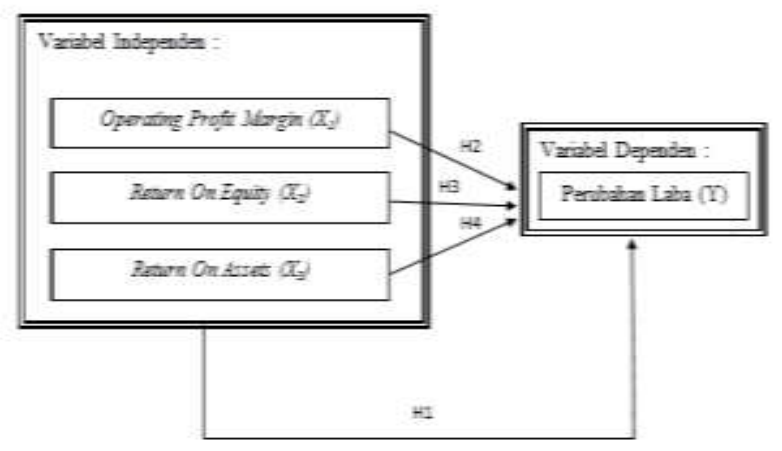

Gambar 1 Model Penelitian

\section{METODE}

Penelitian ini dilakukan dengan menggunakan data laporan keuangan dan laporan tahunan perusahaan-perusahaan lembaga pembiayaan yang terdaftar di Bursa Efek Indonesia (BEI) yang didapat dari www.idx.co.id . Periode laporan keuangan dan laporan tahunan yang digunakan dalam penelitian ini adalah tahun 2011 - 2015. Penelitian menggunakan desain penelitian kausal karena penelitian ini bertujuan untuk menguji hipotesis tentang pengaruh satu atau beberapa variabel (variabel independen) terhadap variabel lainnya (variabel dependen).

Variabel yang digunakan dalam penelitian ini terdiri dari dua jenis yaitu variabel bebas atau independen (OPM, ROE dan ROA) dan variabel terikat atau dependen (perubahan laba). Pengukuran yang digunakan dalam penelitian ini adalah dengan menggunakan skala rasio.

Populasi dalam penelitian ini adalah seluruh perusahaan jasa sektor keuangan subsektor lembaga pembiayaan yang terdaftar di Bursa
Efek Indonesia. Pengambilan sampel dalam penelitian ini menggunakan teknik purposive sampling yang berarti sampel perusahaan yang diambil berdasarkan kriteria tertentu.

Jenis data yang digunakan dalam penelitian ini adalah data sekunder yaitu data yang diperoleh dari dokumen-dokumen perusahaan dan pencatatan yang erat kaitannya dengan masalah yang akan dibahas. Teknik pengumpulan data yang digunakan adalah teknik dokumentasi yaitu pengambilan data dengan cara mencari dan mengumpulkan data yang diperoleh dari laporan keuangan dan laporan tahunan yang dipublikasikan.

Data yang digunakan dalam penelitian ini adalah data panel. Data panel adalah gabungan antara data runtut waktu (time series) dan data silang (cross section). Menurut Widarjono (2013) penggunaan data panel dalam sebuah observasi mempunyai beberapa keuntungan yang diperoleh. Pertama, data panel yang merupakan gabungan dua data time series dan cross section mampu menyediakan data yang lebih banyak sehingga akan lebih menghasilkan degree of freedom yang lebih besar. Kedua, menggabungkan informasi dari data time series dan cross section dapat mengatasi masalah yang timbul ketika ada masalah penghilangan variabel (omitted-variabel). Dalam melakukan analisis dan pengujian hipotesis digunakan alat bantu program komputer EViews 7.2.

\section{HASIL DAN PEMBAHASAN}

\section{Gambaran Umum Objek Penelitian}

Objek penelitian yang digunakan dalam penelitian ini adalah perusahaan pembiayaan yang terdaftar di Bursa Efek Indonesia periode 2011-2015. Sampel dalam penelitian ini ada sebanyak 12 perusahaan dengan menggunakan teknik purposive sampling, dimana sampel penelitian ditentukan berdasarkan kriteria tertentu.

\section{Analisis Regresi Data panel \\ 1. Uji Stasioner}

Salah satu cara untuk melakukan uji stasioner adalah dengan uji akar unit (Unit Root Test). Uji akar unit yang digunakan dalam penelitian ini adalah uji Augmented Dickey-Fuller (ADF) dan memperoleh hasil sebagai berikut : 
Tabel 1

Uji Akar-Akar Unit

\begin{tabular}{|c|c|c|c|}
\hline No & Variabel & Probabilitas & Simpulan \\
\hline 1. & $\begin{array}{c}\text { Perubahan } \\
\text { Laba }\end{array}$ & 0,0000 & Stasioner \\
\hline 2. & OPM & 0,0000 & Stasioner \\
\hline 3. & ROE & 0,0006 & Stasioner \\
\hline 4. & ROA & 0,0000 & Stasioner \\
\hline
\end{tabular}

Sumber : Hasil Pengolahan Data

Data yang stasioner dilihat dari nilai probabilitas dibawah 5\%. Dari hasil olah data dengan software eviews di atas dapat dilihat bahwa dengan metode Augmented Dickey-Fuller nilai probabilitas perubahan laba,OPM, ROE dan ROA adalah lebih kecil dari 5\% dan informasi tersebut menunjukkan bahwa semua variabel stasioner.

\section{Pemilihan Model Estimasi Data Panel}

Dalam penentuan metode regresi panel dapat dilakukan dengan menggunakan tiga cara yaitu Uji Chow, Uji Hausman dan Uji Lagrange Multiplier (LM). Berikut hasil Uji chow pada Eviews 7.2 :

Tabel 2

Uji Chow

Redundant Fixed Effects Tests

Pool: OLAH_DATA

Test cross-section fixed effects

\begin{tabular}{lcrc}
\hline \hline Effects Test & Statistic & d.f. & Prob. \\
\hline \hline Cross-section F & 0.000000 & $(59,3537)$ & 1.0000 \\
Cross-section Chi-square & 0.000000 & 59 & 1.0000 \\
\hline \hline
\end{tabular}

Sumber : Data Sekunder yang Diolah dengan Software Eviews 7.2

Hipotesis dalam uji chow adalah:

HO : Common Effect Model atau Pooled Least Square

H1 : Fixed Effect Model

Dalam uji Chow membandingkan perhitungan Fstatistik dengan F-tabel dan dari perhitungan menggunakan Eviews didapatkan hasil $\mathrm{F}$ hitung 0,00000 lebih kecil $(<)$ dari F tabel 1,0000. Dari hasil di atas dapat dilihat bahwa probabilitas data sebesar 1,0000 lebih besar (>) dari 5\% sehingga $\mathrm{H}_{\mathrm{o}}$ diterima berarti model yang digunakan adalah Common Effect (PLS). Dengan demikian jika sudah ditentukan model yang digunakan dari uji chow adalah Common Effect (PLS). Dari hasil estimasi dengan menggunakan model common effect dapat dibentuk persamaan sebagai berikut :

$\begin{array}{ccc}\text { PERUBAHAN_LABA } & -6,54551 & + \\ & 0.147901 * \mathrm{OPM} & + \\ & 2,776101 * \mathrm{ROE} & - \\ & 4,232647 * \mathrm{ROA}\end{array}$

Persamaan diatas menggambarkan hubungan antara masing-masing variabel independen terhadap variabel dependen. Nilai koefisien regresi OPM sebesar 0,147901 artinya apabila OPM mengalami kenaikan sebesar 1 sedangkan variabel lainnya dianggap konstan, maka perubahan laba mengalami peningkatan sebesar 0,147901 . Nilai koefisien regresi ROE sebesar 2,776101 artinya apabila ROE mengalami kenaikan sebesa-r 1 sedangkan variabel lainnya dianggap konstan, maka perubahan laba mengalami kenaikan sebesar 2,776101. Nilai koefisien regresi ROA sebesar 4,232647 artinya apabila ROA mengalami kenaikan sebesar 1 sedangkan variabel lainnya dianggap konstan, maka perubahan laba mengalami penurunan sebesar 4,232647.

\section{Pengujian Hipotesis}

\section{a. Uji Simultan (Uji F)}

+ Uji F dilakukan untuk mengetahui apakah + variabel independen memiliki pengaruh secara - bersama-sama (simultan) terhadap variabel dependen. Berikut hasil dari pengujian regresi data panel dengan metode common effect : 


\title{
Tabel 3 \\ Uji Regresi Simultan (Uji F)
}

\author{
Dependent Variable: PERUBAHAN_LABA \\ Method: Pooled Least Squares \\ Date: 03/16/17 Time: 20:56 \\ Sample: 160 \\ Included observations: 60 \\ Cross-sections included: 60 \\ Total pool (balanced) observations: 3600
}

\begin{tabular}{lrll}
\hline \hline R-squared & 0.021341 & Mean dependent var & 16.02950 \\
Adjusted R-squared & 0.020524 & S.D. dependent var & 106.3485 \\
S.E. of regression & 105.2515 & Akaike info criterion & 12.15169 \\
Sum squared resid & 39836077 & Schwarz criterion & 12.15857 \\
Log likelihood & -21869.05 & Hannan-Quinn criter. & 12.15414 \\
F-statistic & 26.13803 & Durbin-Watson stat & 2.012144 \\
Prob(F-statistic) & 0.000000 & & \\
\hline \hline
\end{tabular}

Sumber : Data Sekunder yang Diolah dengan Software Eviews 7.2

Dari tabel diatas dapat dilihat nilai probabilitas adalah 0,0000 lebih kecil $(<)$ dari 5\% yang menunjukkan bahwa perubahan laba pada perusahaan pembiayaan dipengaruhi oleh OPM, ROE dan ROA. Nilai $R^{2}$ sebesar 0,021341 menunjukkan bahwa pengaruh OPM, ROE dan ROA terhadap perubahan laba pada perusahaan pembiayaan yaitu sebesar $2,13 \%$ dan sisanya $97,87 \%$ dijelaskan oleh variabel lain.

\section{b. Uji Parsial (Uji t)}

Pengujian ini bertujuan untuk menguji pengaruh OPM, ROE dan ROA terhadap perubahan laba pada tingkat signifikansi 5\% secara parsial. Berikut hasil pengujian signifikansi $t$ yang diperoleh dari model ini :

\section{Tabel 4}

Hasil Uji t

\begin{tabular}{|c|l|l|l|l|l|l|}
\hline No. & Variabel & Regresi & \multicolumn{1}{|c|}{ Konstanta } & Coefficient & Prob. & Signifikansi \\
\hline 1. & OPM & $\mathrm{Y}=\mathrm{a}+\mathrm{b}^{*} \mathrm{OPM}$ & 18,51489 & $-0,094629$ & 0,4000 & Tidak berpengaruh \\
\hline 2. & ROE & $\mathrm{Y}=\mathrm{a}+\mathrm{b}^{*} \mathrm{ROE}$ & $-8,986476$ & 2,007568 & 0,0000 & Berpengaruh $(+)$ \\
\hline 3. & ROA & $\mathrm{Y}=\mathrm{a}+\mathrm{b}^{*} \mathrm{ROA}$ & 8,181161 & 2.026424 & 0,0096 & Berpengaruh $(+)$ \\
\hline
\end{tabular}

Sumber : Hasil Pengolahan Data

Dari tabel diatas dapat dilihat bahwa nilai koefisien konstanta adalah 18,51489 dan nilai koefisien OPM adalah -0,094629 yang menjelaskan besar pengaruh OPM terhadap perubahan laba sebesar -0,094629. Nilai probabilitas $0,40>0,05$ maka dikatakan $\mathrm{H}_{0}$ diterima dan $\mathrm{H}_{1}$ ditolak maka dapat disimpulkan OPM tidak berpengaruh terhadap perubahan laba. Nilai koefisien konstanta ROE adalah -8,986476 dan nilai koefisien ROE adalah 2,007568 yang menjelaskan besar pengaruh ROE terhadap perubahan laba sebesar 2,007568. Nilai probabilitas $0,00<0,05$ maka dikatakan $\mathrm{H}_{0}$ ditolak dan $\mathrm{H}_{1}$ diterima maka dapat disimpulkan
ROE berpengaruh positif dan signifikan terhadap perubahan laba.

Dari tabel diatas dapat dilihat bahwa nilai koefisien konstanta adalah 8,181161 dan nilai koefisien ROA adalah 2.026424 yang menjelaskan besar pengaruh ROA terhadap perubahan laba sebesar 2.026424. Nilai probabilitas $0,00<0,05$ maka dikatakan $\mathrm{H}_{0}$ ditolak dan $\mathrm{H}_{1}$ diterima maka dapat disimpulkan ROA berpengaruh positif dan signifikan terhadap perubahan laba. 


\section{Pengaruh Operating Profit Margin terhadap Perubahan Laba}

Hasil dari pengujian hipotesis menunjukkan bahwa OPM bernilai negatif namun tidak berpengaruh signifikan terhadap perubahan laba. Hal ini menunjukkan penurunan OPM akan menurunkan perubahan laba namun pengaruhnya tidak signifikan pada perusahaan pembiayaan yang terdaftar di BEI. Rasio operating profit margin adalah untuk mengukur efisiensi operasi perusahaan dalam menghasilkan laba dengan membandingkan laba operasi atas penjualan. Hasil penelitian yang menyatakan tidak berpengaruh signifikan menunjukkan bahwa penurunan laba tidak hanya dipengaruhi oleh perubahan OPM namun dapat juga dipengaruhi oleh faktor lain. Faktor lain penyebab perubahan laba misalnya perubahan penjualan, perubahan harga pokok penjualan, perubahan beban operasi, perubahan beban bunga, perubahan pajak penghasilan, adanya perubahan dalam pos-pos luar biasa, dan lain-lain.

Hasil penelitian ini berbeda dengan penelitian sebelumnya yang dilakukan oleh Hendra Agus Wibowo dan Diyah Pujiati (2011) yang menyatakan OPM berpengaruh signifikan terhadap perubahan laba.

\section{Pengaruh Return On Equity terhadap Perubahan Laba}

Hasil dari pengujian hipotesis menunjukkan bahwa ROE bernilai positif dan berpengaruh signifikan terhadap perubahan laba. Hubungan antara ROE dengan perubahan laba yang positif berarti bahwa kenaikan variabel ROE dapat menaikkan perubahan laba. Pengaruh yang signifikan berarti kemampuan perusahaan dalam menghasilkan laba dengan memanfaatkan modal saham berpengaruh terhadap perubahan laba. Hal ini mengindikasikan bahwa penggunaan modal saham perusahaan efektif dalam menghasilkan laba pada perusahaan pembiayaan yang terdaftar di BEI.

Hasil penelitian ini mendukung penelitian sebelumnya yang dilakukan oleh Siti Syarifah (2014) yang menyatakan ROE berpengaruh positif dan signifikan terhadap perubahan laba.

\section{Pengaruh Return On Assets (ROA) terhadap Perubahan Laba}

Hasil dari pengujian hipotesis menunjukkan bahwa ROA berpengaruh positif dan pengaruhnya signifikan terhadap perubahan laba. Ini berarti kemampuan perusahaan dalam menghasilkan laba dengan memanfaatkan aktiva (dalam hal penjualan) berpengaruh terhadap perubahan laba. Nilai ROA yang positif berarti peningkatan ROA akan menaikkan perubahan laba. Hal ini mengindikasikan pada pemanfaatan aset yang efektif dalam menghasilkan laba perusahaan. Pembelian aset-aset perusahaan ditujukan untuk meningkatkan laba.

Hasil penelitian ini mendukung penelitian sebelumnya yang dilakukan oleh Ghazali Syamni dan Martunis (2013) menunjukkan ROA berpengaruh positif dan signifikan terhadap perubahan laba.

\section{SIMPULAN DAN SARAN}

Berdasarkan analisis yang telah dilakukan dapat ditarik kesimpulan bahwa hasil uji simultan (Uji F), diperoleh hasil bahwa Operating Profit Margin, Return On Equity dan Return On Assets memiliki pengaruh secara simultan terhadap perubahan laba. Berdasarkan hasil uji t, diperoleh hasil bahwa Operating Profit Margin tidak berpengaruh signifikan terhadap perubahan laba. Return On Equity berpengaruh positif dan signifikan terhadap perubahan laba. Return On Assets berpengaruh positif dan signifikan terhadap perubahan laba.

Berdasarkan hasil penelitian rasio OPM dan ROA dapat dijadikan pertimbangan dalam pengambilan keputusan berinvestasi dimana rasio-rasio tersebut berpengaruh terhadap laba yang dihasilkan perusahaan di masa yang akan datang. Penelitian ini diharapkan dapat menjadi tambahan referensi bagi penelitian selanjutnya terkait hal yang sama untuk dikembangkan dan diperbaiki, misalnya dengan menambah variabel independen, periode pengamatan ataupun jumlah sampel agar hasil penelitian lebih akurat.

\section{DAFTAR RUJUKAN}
Hanafi, M. H. \& Halim A.(2007). Analisa Laporan Keuangan Edisi Ketiga. Yogyakarta: YUPP STIM YKPN.

Kasmir. (2014). Analisis Laporan Keuangan. Jakarta: PT Raja Grafindo Persada.

Naser, Abdul. (2011). Kontribusi Rasio Keuangan Terhadap Perubahan Laba Perbankan di Bursa Efek Jakarta. Jurnal 
Bisnis dan Manajemen Vol. 9 No.3, 300462.

Sudana, I Made.(2011). Manajemen Keuangan Perusahaan Teori dan Praktek.Jakarta: Erlangga.

Syamni G.\& Martunis. (2013). Pengaruh OPM, ROE, dan ROA terhadap Perubahan Laba pada Perusahaan Telekomunikasi di Bursa Efek Indonesia, Jurnal Kebangsaan Vol. 2 No. 4, 2089-5917.

Syarifah, S. (2014). Pengaruh Rasio Leverage dan Profitabilitas terhadap Perubahan Laba pada Perusahaan Sektor Aneka Industri yang terdaftar di Bursa Efek Indonesia Periode 2010-201. E-Journal Universitas Maritim Raja Ali Haji. (jurnal.umrah.ac.id/p=3030 diakses pada 12 Februari 2017 jam 20.00 WIB)

Wibowo, H. A.\& Pujiati D. (2011). Analisis Laporan Keuangan dalam Memprediksi Perubahan Laba pada Perusahaan Real Estate dan Property di Bursa Efek Indonesia ( BEI ) dan Singapura ( SGX ), The Indonesian Accounting Review, 155178.

Widarjono, A. (2013). Ekonometrika Pengantar dan Aplikasinya. Edisi Keempat. Yogyakarta: UPP STIM YKPN.

Widhi, Metta S. (2011). Analisis Rasio-Rasio Keuangan Dalam Memprediksi Perubahan Laba. Skripsi, Program Studi Akuntansi Fakultas Ekonomi Universitas Diponegoro Semarang (tidak dipublikasikan).

http://www.idx.co.id/id $\mathrm{id} /$ beranda/publikasi/ringkasankinerjaperus ahaantercatat.aspx 